University of Nebraska - Lincoln

DigitalCommons@University of Nebraska - Lincoln

2005

\title{
Chlorovirus: A Genus of Phycodnaviridae that Infects Certain Chlorella-Like Green Algae
}

\author{
Ming Kang \\ University of Nebraska-Lincoln, mkang2@unl.edu \\ David Dunigan \\ University of Nebraska-Lincoln, ddunigan2@unl.edu \\ James L. Van Etten \\ University of Nebraska-Lincoln, jvanetten1@unl.edu
}

Follow this and additional works at: https://digitalcommons.unl.edu/plantpathpapers

Part of the Plant Pathology Commons

Kang, Ming; Dunigan, David; and Van Etten, James L., "Chlorovirus: A Genus of Phycodnaviridae that Infects Certain Chlorella-Like Green Algae" (2005). Papers in Plant Pathology. 130.

https://digitalcommons.unl.edu/plantpathpapers/130

This Article is brought to you for free and open access by the Plant Pathology Department at DigitalCommons@University of Nebraska - Lincoln. It has been accepted for inclusion in Papers in Plant Pathology by an authorized administrator of DigitalCommons@University of Nebraska - Lincoln. 


\title{
Chlorovirus: a genus of Phycodnaviridae that infects certain chlorella-like green algae
}

\author{
Ming Kang, ${ }^{1}$ David D. Dunigan, ${ }^{1,2}$ and James L. Van Etten ${ }^{1,2}$
}

${ }^{1}$ Department of Plant Pathology and ${ }^{2}$ Nebraska Center for Virology, University of Nebraska-Lincoln, Lincoln, NE 68583-0722, USA
Correspondence- M. Kang, mkang2@unInotes.unl.edu ; J. L. Van Etten, jvanetten@unlnotes.unl.edu

\section{Abstract}

Taxonomy: Chlorella viruses are assigned to the family Phycodnaviridae, genus Chlorovirus, and are divided into three species: Chlorella NC64A viruses, Chlorella Pbi viruses and Hydra viridis Chlorella viruses. Chlorella viruses are large, icosahedral, plaque-forming, dsDNA viruses that infect certain unicellular, chlorella-like green algae. The type member is Paramecium bursaria chlorella virus 1 (PBCV-1).

Physical properties: Chlorella virus particles are large (molecular weight $\sim 1 \times 10^{9} \mathrm{Da}$ ) and complex. The virion of PBCV-1 contains more than 100 different proteins; the major capsid protein, Vp54, comprises $\sim 40 \%$ of the virus protein. Cryoelectron microscopy and three-dimensional image reconstruction of $\mathrm{PBCV}-1$ virions indicate that the outer glycoprotein-containing capsid shell is icosahedral and surrounds a lipid bilayered membrane. The diameter of the viral capsid ranges from $1650 \AA$ along the two- and three-fold axes to $1900 \AA$ along the five-fold axis. The virus contains 5040 copies of Vp54, and the triangulation number is 169. The PBCV-1 genome is a linear, $330744-$ bp, non-permuted dsDNA with covalently closed hairpin ends. The PBCV-1 genome contains $\sim 375$ protein-encoding genes and 11 tRNA genes. About $50 \%$ of the proteinencoding genes match proteins in the databases.

Hosts: Chlorella NC64A and Chlorella Pbi, the hosts for NC64A viruses and Pbi viruses, respectively, are endosymbionts of the protozoan Paramecium bursaria. However, they can be grown in the laboratory free of both the paramecium and the virus. These two chlorella species are hosts to viruses that have been isolated from fresh water collected around the world. The host for hydra chlorella virus, a symbiotic chlorella from Hydra viridis, has not been grown independently of its host; thus the virus can only be obtained from chlorella cells freshly released from hydra.

\section{INTRODUCTION}

The chlorella viruses are large, icosahedral, plaque-forming, dsDNA viruses that infect certain unicellular, chlorellalike green algae (Van Etten et al., 1991). They belong to the family Phycodnaviridae, genus Chlorovirus. This genus consists of three species: NC64A viruses, which infect Chlorella NC64A, have been isolated from fresh water collected in the United States (Van Etten et al., 1985a), China (Zhang et al., 1988), Japan, Brazil (Yamada et al., 1991), Argentina, Australia, Israel, and Italy (J.L.V.E., unpublished results); Pbi viruses, which infect Chlorella Pbi, were first detected in fresh water collected in Europe (Reisser et al., 1988), and subsequently in water collected in Australia, Canada and the northern United States or at higher elevations in the western United States (M. Nelson and J.L.V.E., unpublished results). Typically, the NC64A and Pbi virus titers in native waters are 1-100 plaque-forming units (PFU)/mL, but they fluctuate seasonally, with the highest titers usually found in the spring (Van Etten et al., 1985b; Yamada et al., 1991). Titers as high as 100000 $\mathrm{PFU} / \mathrm{mL}$ of native water have been obtained (M. Nelson and J.L.V.E., unpublished results). The viruses that infect Chlorella NC64A neither infect nor attach to Chlorella Pbi, and vice versa. In nature Chlorella NC64A and Chlorella Pbi are hereditary endosymbionts in green isolates of the protozoan Paramecium bursaria (Figure 1A). Certain endosymbiotic algae, also termed zoochlorella, can be grown in the laboratory free of both the paramecium and the virus and serve as hosts for the chlorella viruses (Figure 1B). The lytic chlorella viruses can be reproduced in large quantities and assayed by plaque formation using standard bacteriophage-like techniques (Figure 1C) (Van Etten et al., 1983a). The prototype chlorella virus is Paramecium bursaria chlorella virus 1 (PBCV-1). The third species in the genus Chlorovirus infects symbiotic chlorella in the coelenterate Hydra viridis. These lytic viruses are similar morphologically and biochemically with the other chlorella viruses. However, this chlorella host has not been cultured, and thus the virus only can be obtained from chlorella cells freshly released from hydra. 

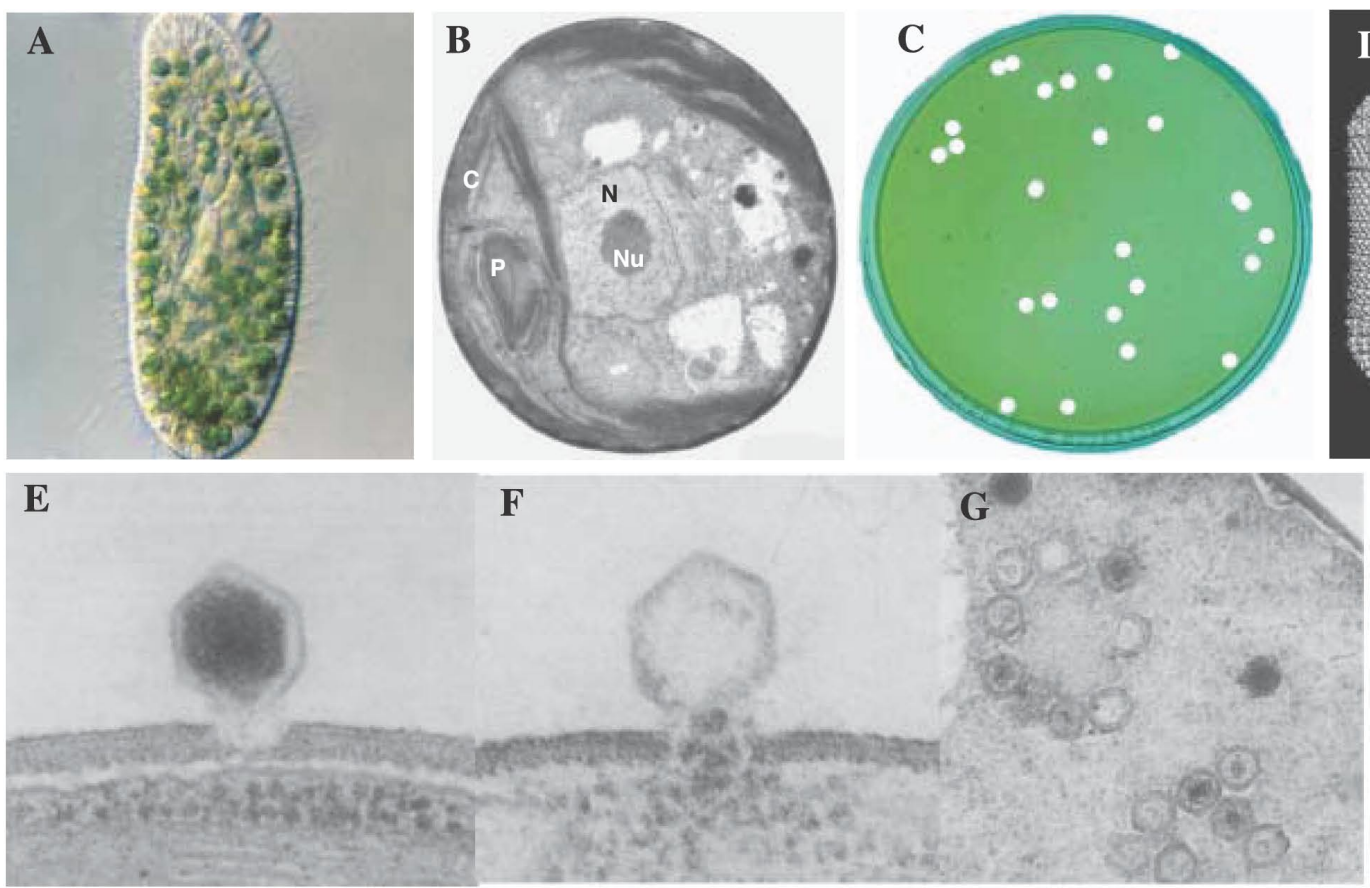

Figure 1 Chlorella cells and chlorella virus PBCV-1. (A) Paramecium bursaria and its symbiotic Chlorella cells. The size of Paramecium bursaria is 100-150 × 50-60 $\mu \mathrm{m}$. (B) Thin section of a Chlorella cell ( 5 $\mu \mathrm{m}$ in diameter). Abbreviations: $\mathrm{N}$, nucleus; Nu, nucleolus; C, chloroplast; P, pyrenoid. (C) Plaques formed by PBCV-1 on a lawn of Chlorella NC64A. (D) Cryoelectron microscopy and three-dimensional reconstruction of PBCV-1 virion. The diameter is $1650 \AA$ along the two- and three-fold axes and $1900 \AA$ along the five-fold axis. (EH) Replication of PBCV-1. (E) Attachment of PBCV-1 to the algal wall and digestion of the wall at the point of attachment. This event occurs within 1-5 min p.i. (F) Viral DNA, possibly with associated proteins, is ejected into the host cell (3-6 min p.i.). (G) Virion particles assemble in defined areas in the cytoplasm, named virus assembly centers (labeled by $\mathrm{v})(3-5 \mathrm{~h}$ p.i.). (H) Localized lysis of the cell wall and release of progeny viruses.

Algae assigned to the genus Chlorella are small spherical or ellipsoidal, unicellular, non-motile, asexually reproducing green cells and are among the most widely distributed and frequently encountered algae (Shihra and Krauss, 1965). Most chlorella species are free living except for the few that are symbionts in other organisms. The only known hosts for the chlorella viruses are symbiotic chlorella; fortunately some of these symbionts can be cultured.

\section{THE VIRION}

Chlorella virus particles are large (molecular weight $\sim 1 \times 10^{9} \mathrm{Da}$ ) and complex. The PBCV-1 virion contains more than 100 different virus-encoded proteins (Skrdla et al., 1984; D.D.D., R. Cerny and J.L.V.E., unpublished results). The PBCV-1 54-kDa major capsid protein (Vp54) is a glycoprotein and comprises $\sim 40 \%$ of the total virus protein. The Vp54 molecule consists of two eight-stranded, anti-parallel $\beta$-barrel, jelly-roll domains related by pseudo-sixfold rotation (Nandhagopal et al., 2002). This structure resembles the major coat proteins from some other dsDNA viruses such as bacteriophage PRD1, and human adenoviruses, as well as the viral protein VP2-VP3 of picornaviruses. Cryoelectron microscopy and three-dimensional image reconstruction of the PBCV-1 virion (26-Å resolution) indicate that the outer capsid is icosahedral and covers a lipid bilayered membrane (Yan et al., 2000). The membrane is necessary for infection, because the virus loses infectivity quickly in chloroform and more slowly in ethyl ether or toluene (Skrdla et al., 1984). The outer diameter of the viral capsid ranges from $1650 \AA$ along the two- and three-fold axes to $1900 \AA$ along the fivefold axis. The capsid shell consists of 1680 doughnut-shaped trimeric capsomers plus 12 pentameric capsomers at each icosahedral vertex. Assuming all the trimeric capsomers are identical, the outer capsid of the virus contains 5040 copies of Vp54. The virus has a triangulation number of 169 (Figure 1D) (Yan et al., 2000).

\section{THE GENOME}

The PBCV-1 genome is a linear, 330-kbp, non-permuted dsDNA with covalently closed hairpin ends (Figure 2) (Girton and Van Etten, 1987; Rohozinski et al., 1989). The termini consist of 35-nt-long, partially base-paired, covalently closed hairpin loops (Zhang et al., 1994). A 2221-bp inverted repeat is adjacent to each of the termini, and the rest of the genome consists primarily of single copy DNA (Girton and Van Etten, 1987; Strasser et al., 1991). One unusual feature of PBCV1 DNA, as well as other chlorella virus DNAs, is that they contain methylated bases. DNA from each of 37 chlorella viruses contains 5 -methylcytosine $(5 \mathrm{mC})$ in amounts varying 


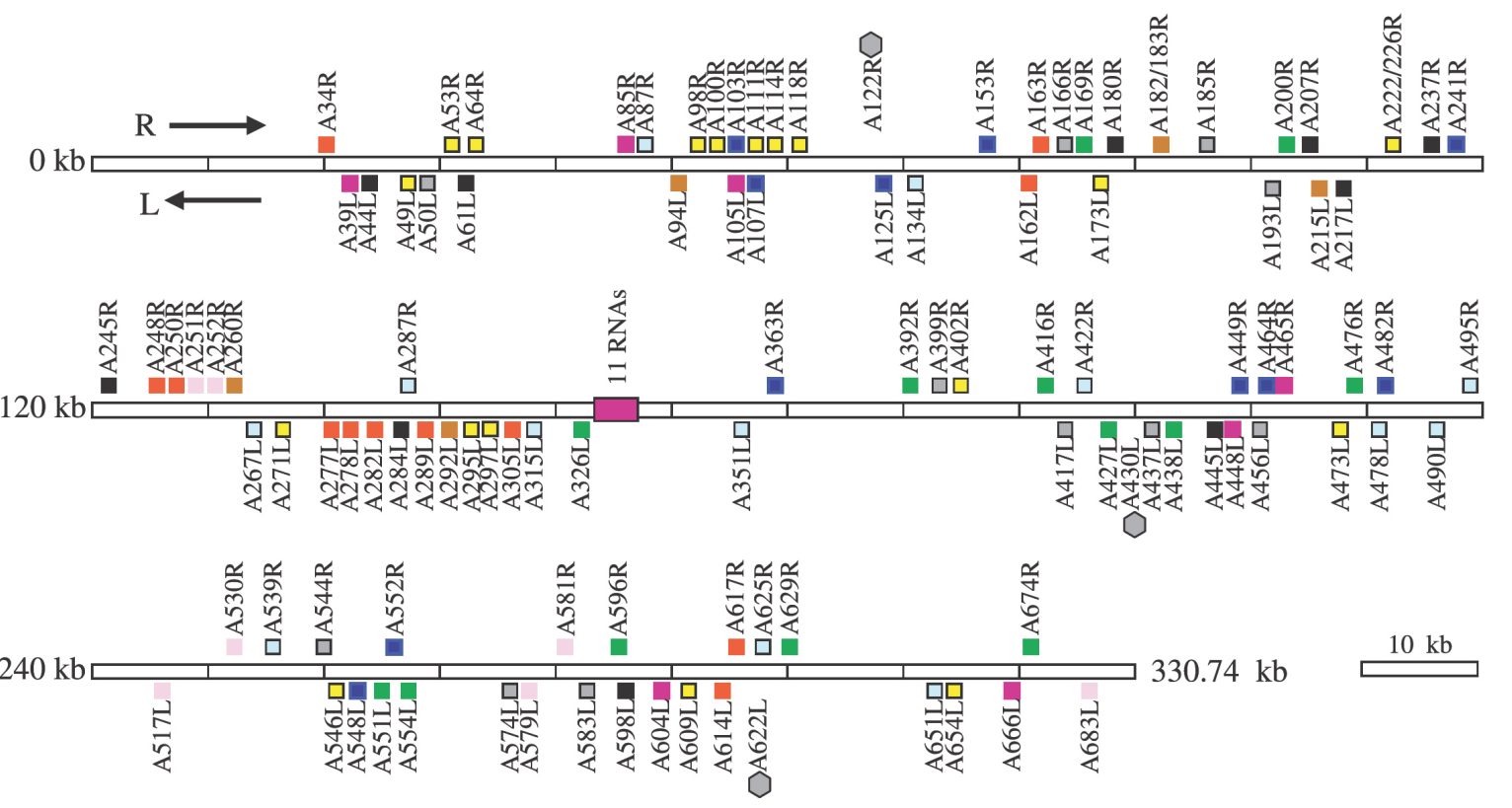

$\square$ MetabolismDNA Replication, Recombination, and Repair

$\begin{array}{lll}\text { (E) } & \text { A185R } & \text { } 1 \text { DNA polymerase } \\ \text { (E) } & \text { A544R* } & \text { ATP-dependent DNA ligase } \\ \text { (E) } & \text { A583L* } & \text { DNA topoisomerase II } \\ \text { A192 } & \text { PCNA } \\ & \text { A574L } & \text { PCNA } \\ & \text { A399R } & \text { RNaseH } \\ & \text { A456L } & \text { Superfamily III helicase }\end{array}$

A456L Superfamily III helicase

C) A50L* Pyrimidine dimer-specific glycosylase A417L Replication factor C

(E) A166R* Exonuclease

$\square$ Nucleotide Metablism

(E) A169R* Aspartate transcarbamylase A476R Ribo. reductase (small subunit) A629R Ribo. reductase (large subunit) A427L Thioredoxin

(E) A55IL $^{*}$ dUTP pyrophosphatase A596R* dCMP deaminase A416R $\quad$ dG/dA kinase

$\begin{array}{ll}\text { A416R } & \text { dG/dA kinase } \\ \text { A326L } & \text { NTP pyrophosphohydrolase }\end{array}$

A200R Cytidine deaminase

A674R* Thymidylate synthase $X$

$\begin{array}{ll}\text { A554L } & \text { ATPase } \\ \text { A392R } & \text { ATPase }\end{array}$

Transcription

$\begin{array}{ll}\text { A107L } & \text { Transcription factor TFIIB } \\ \text { A125L } & \text { Transcription factor TFIIS }\end{array}$

(E) A552R Transcription factor TFIID A482R VLTF2-type transcription factor

(E) A103R* RNA guanylyltransferase A449R* RNA triphosphatase A153R Superfamily II helicase

A363R Superfamily II helicase

(E) A464R* RNase II A548L SWI/SNF helicase A241R Skil helicase

(L) A612L* Histone H3, Lys27 methylase

$\square$ Protein Synthesis, Modification, and Degradation

\begin{tabular}{|c|c|c|}
\hline & $\mathrm{A} 39 \mathrm{~L}$ & SKP-1 protein \\
\hline & & Translation elongation factor-3 \\
\hline & A85R* & Prolyl 4-hydroxylase \\
\hline & A105L & Ubiquitin C-terminal hydrolase \\
\hline & A448L & Protein disulphide isomerase \\
\hline & A465R & Thiol oxidoreductase \\
\hline & A604L & Zn metallopeptidase \\
\hline & & \\
\hline
\end{tabular}

Cell Wall Degrading Enzymes

$\begin{array}{lll}\text { (E) } & \text { A94L* } & \beta \text {-1,3-glucanase } \\ \text { (E) } & \text { A181/182R* } & \text { Chitinase } \\ \text { (L) } & \text { 2260R* } & \text { Chitinas } \\ \text { (L) A292L* } & \text { Chitosanase } \\ \text { (E,L) } & \text { A215L* } & \text { Alginate lyase }\end{array}$

$\square$ Sugar and Lipid Manipulation

$\begin{array}{lll}\text { (E) } & \text { A98R* } & \text { Hyaluronan synthase } \\ \text { (E) } & \text { A100R* }^{*} & \text { Glucosamine synthase }\end{array}$

$\begin{array}{lll}\text { (E) } & \text { A100R* } & \text { Glucosamine synthase } \\ \text { (E) } & \text { A609L* } & \text { UDP-glucose dehydrogenase }\end{array}$

$\begin{array}{lll}\text { (E) A609L* } & \text { UDP-glucose dehydrogenase } \\ \text { (E) } & \text { A118R* } & \text { GDP-D-mannose dehydratase }\end{array}$

(E) A295L* Fucose synthase

(E,L) A64R Mannosyltransferase

A111R Glycosyltransferase

A114R Fucosyltransferase

A222/226R Glycosyltransferase

(E) A473L Glycosyltransferase

A546L Glycosyltransferase

A49L Glycerophosphoryl diesterase

A53R 2-hydroxyacid dehydrogenase

A173L Patatin phospholipase

A271L Lysophospholipase

A297L Fructose-2,6-bisphosphatase

A402R Lipoprotein lipase

N-acetyltransferase

Signaling

(E,L) A250R* $\quad \mathrm{K}^{+}$channel protein

A162L Ligand-gated channel protein

A163R Ligand-gated channel protein

A34R* Ser/Thr protein kinase

(L) A248R* Ser/Thr Protein kinase

A277L Ser/Thr protein kinase

A278L* $\quad$ Ser/Thr protein kinase

A282L* Ser/Thr protein kinase

A289L* $\quad$ Ser/Thr protein kinase

A305L Tyr phosphatase

$\begin{array}{ll}\text { A614L* } & \text { Protein Kinase } \\ \text { A617R } & \text { Tyr-protein kinase }\end{array}$

$\square$ DNA Restriction/Modification

A251R* Adenine DNA methylase [M. CviAII]

A252R* DNA restriction endonuclease [R. CviAII]

(E) A517L* Cytosine DNA methylase [M. CviAIII]

(L) A530R* Cytosine DNA methylase [M. CviAIV]

(E) A581R* Adenine DNA methylase [M. CviAI]

(E) A579L* DNA restriction endonuclease [R. CviAI]

A683L Cytosine DNA methyltransferase [M.CviAV](E,L)
Integration and Transposition

$\begin{array}{ll}\text { A625R } & \text { Transposase } \\ \text { A134L } & \text { Homing endonuclease GIY-YIG } \\ \text { A287R } & \text { Homing endonuclease GIY-YIG } \\ \text { A315L } & \text { Homing endonuclease GIY-YIG } \\ \text { A351L } & \text { Homing endonuclease GIY-YIG } \\ \text { A495R } & \text { Homing endonuclease GIY-YIG } \\ \text { A539R } & \text { Homing endonuclease GIY-YIG } \\ \text { A651L } & \text { Homing endonuclease GIY-YIG } \\ \text { A422R } & \text { Homing endonuclease HNH } \\ \text { A87R } & \text { Homing endonuclease HNH } \\ \text { A267L } & \text { Homing endonuclease HNH } \\ \text { A478L } & \text { Homing endonuclease HNH } \\ \text { A490L } & \text { Homing endonuclease HNH(L) }\end{array}$

Miscellaneous

(E,L) A207R* Ornithine decarboxylase

(L) A237R* Homospermidine synthase

(E) A78R* N-carbamoylput amidohydrolase

(E) A638R* Agmatine iminohydrolase

A217L Monoamine oxidase

A44L BCS1 protein

A61L O-methyltransferase

A180R Fibronectin binding protein

A245R* $\quad \mathrm{Cu} / \mathrm{Zn}$-superoxide dismutase

A284L* Amidase

A445L ABC transporter protein

Structural Proteins

(L) A430L $\quad \mathrm{V} 554$, major coat protein

(L) A622L Coat protein-like

A122R Glycoprotein Vp260
* Functional enzyme
(E) Early gene
(L) Late gene

Figure 2. Partial gene map of the PBCV-1 genome. Genes listed above the genome are transcribed from left to right (R, $\rightarrow$ ), and genes listed below the genome are transcribed from right to left $(\mathrm{L}, \leftarrow)$. The genes that have similar or related function are assigned into the same group and are labeled by a code in the same color. *Genes characterized and known to encode functional enzymes. (E) Genes transcribed early; (L) genes transcribed late. For many genes both the transcription patterns and the functions of gene products are unknown. 
from $0.12 \%$ to $47.5 \%$ of the total cytosines. Twenty-four of the 37 viral DNAs contain $\mathrm{N}^{6}$-methyladenine $(6 \mathrm{~mA})$ ranging from $1.5 \%$ to $37 \%$ of the total adenines (Van Etten et al., 1991). Sequence analysis of the 330-kb PBCV-1 genome revealed 700 open reading frames (ORFs) of 65 codons or larger (Kutish et al., 1996; Li et al., 1995, 1997; Lu et al., 1995, 1996). About 375 ORFs probably encode proteins. The putative protein-encoding genes are evenly distributed on both strands and the intergenic space is minimal; 275 ORFs are separated by fewer than 100 nucleotides. One exception is a 1788-bp intergenic fragment near the middle of the genome that encodes a polycistron of 11 tRNA genes. About $50 \%$ of the 375 PBCV-1 protein-encoding gene products have been tentatively identified and include both prokaryotic- and eukaryoticlike proteins (Figure 2). Many of these ORFs have never been seen in viruses before, such as ornithine decarboxylase, fucose synthase and histone H3, Lys 27 methylase.

Genes shared between PBCV-1 and other chlorella virus isolates may differ in nucleotide sequence by as much as $50 \%$, which translates into amino acid sequence differences of $>40 \%$. Thus, ORF sequence comparisons can identify conserved amino acids in proteins, as well as regions that tolerate amino acid changes. Many PBCV-1-encoded proteins are either the smallest or among the smallest proteins of their class. Their small sizes and the finding that many virus-encoded recombinant proteins are 'laboratory friendly' have resulted in the proteins serving as models for structure and mechanistic studies. Examples include: the smallest known type II DNA topoisomerase, which cleaves dsDNA about 30 times faster than the human enzyme (Fortune et al., 2001); an RNA capping guanylyltransferase, which was the first enzyme of its type to have its crystal structure resolved (Hakansson and Wigley, 1998); and the smallest known protein to form a functional $\mathrm{K}^{+}$channel (Plugge et al., 2000).

Compared with other viruses, the chlorella viruses have some unique features. (i) They encode multiple type II DNA methyltransferases and DNA restriction endonucleases. (ii) Three types of introns have been identified in the PBCV-1 genome: a self-splicing intron in a transcription factor TFIIS-like gene (Li et al., 1995; Yamada et al., 1994), a spliceosomalprocessed intron in a DNA polymerase gene (Grabherr et al., 1992) and a small intron in one of the tRNA genes (Nishida et al., 1999). (iii) Unlike other glycoprotein-containing viruses, PBCV-1 encodes most, if not all, of the gene products required to glycosylate its proteins.

\section{THE LIFE CYCLE}

PBCV-1 infects its host by rapid and irreversible attachment to the external surface of the algal cell wall (Meints et al., 1984). Attachment occurs at a virus vertex and is followed by degradation of the host wall at the attachment point and entry of the viral DNA and probably associated proteins into the cell (Figs $1 \mathrm{E}$ and 3 ). The process leaves an empty but intact virus particle on the surface of the cell (Figure 1F). Circumstantial evidence suggests that the viral DNA and some presumptive
DNA-associated proteins quickly move to the nucleus where early transcription is detected within 5-10 min post infection (p.i.). However, there is no direct evidence indicating that the viral DNA enters the nucleus. Virus DNA replication starts 60-90 min p.i. followed by transcription of virus late genes (Schuster et al., 1986; Van Etten et al., 1984). About 2 h p.i., capsids begin to assemble in localized regions of the cytoplasm, called virus assembly centers, which become dominant at 3-4 h p.i. (Figs $1 \mathrm{G}$ and 3). By $5 \mathrm{~h}$ p.i. the cytoplasm becomes abundant with progeny virus particles ( 1000 particles/cell) and by $6-8 \mathrm{~h}$ p.i. the cell lyses and releases progeny viruses (Figs $1 \mathrm{H}$ and 3 ). Thirty to $50 \%$ of the progeny particles are infectious; thus each infected cell produces $\sim 350$ PFU (Meints et al., 1986; Van Etten et al., 1983b).

\section{HOST CELL-WALL DIGESTION}

Digestion of the host cell wall is critical to virus infection and progeny virus release. Therefore, it is not surprising that chlorella viruses, e.g. PBCV-1 and CVK1, encode several enzymes that may aid in degradation of the chlorella cell wall, including two chitinases, a chitosanase, a $\beta$-1,3-glucanase, and another enzyme that partially digest Chlorella NC64A cell walls. Recombinant proteins from these five genes have the expected enzyme activities (Hiramatsu et al., 1999, 2000; Suda et al., 1999; Sugimoto et al., 2000; Sun et al., 1999, 2000). One of the chitinases and the chitosanase are produced as late gene products and are packaged in the virion (Sun et al., 1999); presumably these enzymes are involved in host cell-wall degradation during infection. However, incubation of host cells with all five recombinant proteins does not result in protoplast release, indicating that complete cell-wall degradation requires one or more additional enzyme activities. In contrast, a crude enzyme extract isolated from virusinfected cell lysates, termed lysin, digests the host cell walls and results in the release of intact protoplasts (R. H. Meints, unpublished results). Chitin is a normal component of fungal cell walls and the exoskeleton of insects and is not normally present in algae. However, Chlorella Pbi and perhaps Chlorella NC64A contain chitin or chitin-like material in their cell walls (Kapaun and Reisser, 1995; Kapaun et al., 1992).

\section{DNA REPLICATION}

PBCV-1 encodes at least ten putative proteins involved in DNA replication that begins at 60-90 min p.i. (Figure 2). The PBCV-1 DNA polymerase (Grabherr et al., 1992) is a member of the DNA polymerase $\delta$-family and has a proof-reading 3'-5' exonuclease domain. PBCV-1 also encodes two sliding clamp processivity factors (PCNA) that resemble PCNAs from other organisms more than they resemble each other (26\% amino acid identity). PCNAs interact not only with proteins involved in DNA replication, but also with proteins involved in DNA repair and post-replicative processing, such as DNA 
Figure 3. Proposed replication pattern of PBCV-1. The virus uncoats at the surface of the alga and the viral DNA, possibly with associated proteins, is assumed to move to the nucleus where early gene transcription begins within 5-10 min p.i. The early mRNAs are transported to the cytoplasm for translation, and the early proteins presumably return to the nucleus to initiate DNA replication, which begins $60-$ 90 min p.i., followed by late gene transcription. Late mRNAs are transported to the cytoplasm for translation, and many of these late proteins are targeted to the cytoplasmically located virus assembly centers, where virus capsids are formed. The algal cell wall lyses, and infectious PBCV1 progeny viruses are released at 6-8 h p.i. (-) Known events; $(-->)$ hypothesized events.

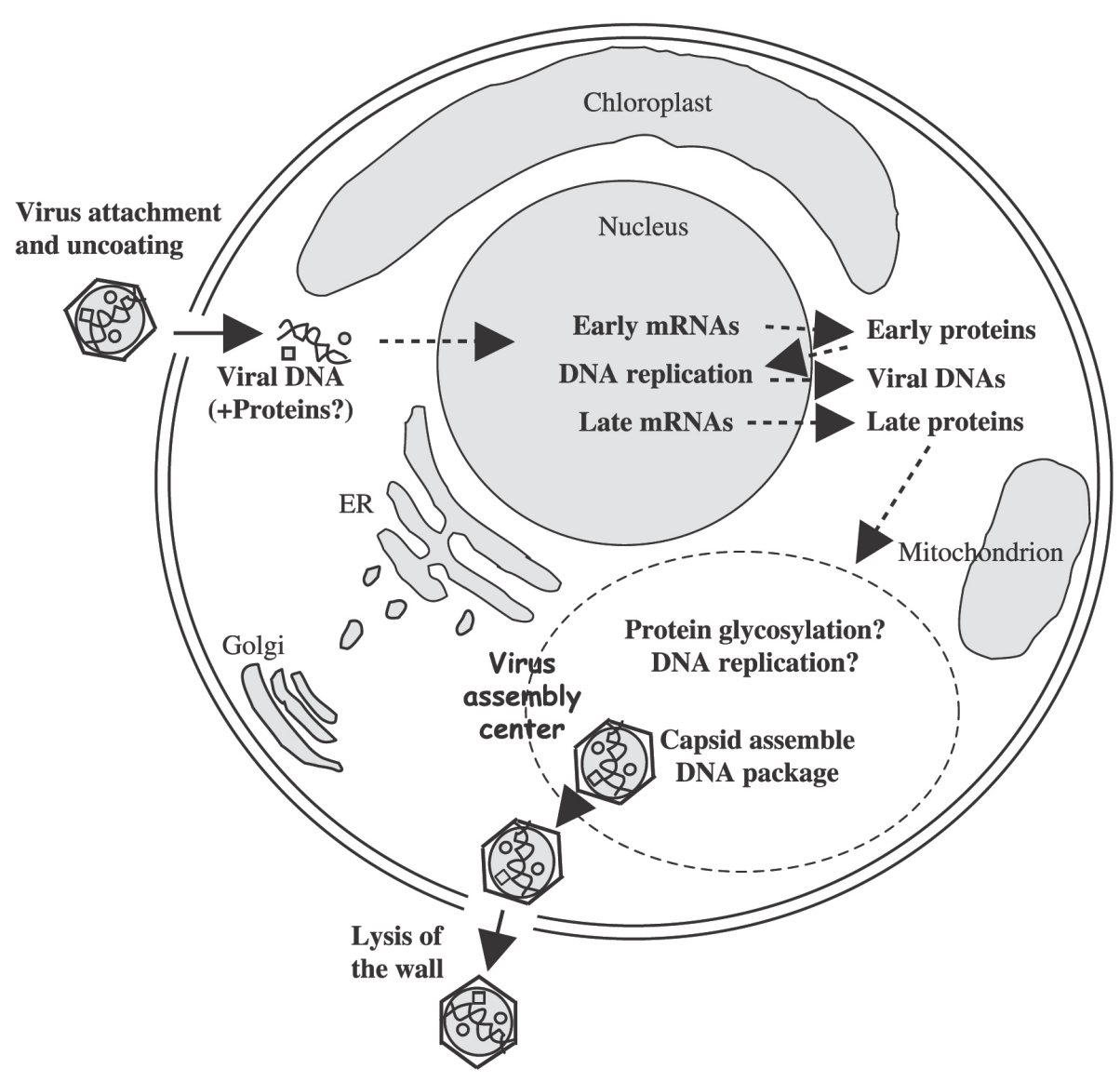

methyltransferases and DNA transposases (Warbrick, 2000). Therefore, the two PBCV-1-encoded PCNAs may have different functions in virus replication. PBCV-1 encodes a single protein that resembles one component of the Archae heterodimer replication factor C complex (RFC) (L. A. Fitzgerald, unpublished results). It is unknown if the PBCV-1-encoded protein can function by itself as an RFC or requires other host proteins for activity. PBCV-1 also encodes other proteins involved in DNA replication. These include an ATP-dependent DNA ligase (Ho et al., 1997), a type II DNA topoisomerase (Lavrukhin et al., 2000) and an RNase H (J.L.V.E., unpublished results). Even if all of the gene products encoded by PBCV-1 are involved in virus DNA replication, they are probably insufficient for DNA replication, suggesting that PBCV-1 relies on some host enzymes to complete this process.

\section{TRANSCRIPTION}

PBCV-1 gene expression can be divided into two stages, early and late, although a few genes are transcribed both early and late. The junction between the two stages occurs at 60-90 min p.i., which coincides with the start of DNA replication. Some general statements about chlorella virus transcription can be made based on two PBCV-1 RNA synthesis studies (Schuster et al., 1986, 1990). (i) Virus infec- tion inhibits host RNA synthesis. (ii) PBCV-1 transcription is programmed and the first transcripts appear between 5 and 10 min p.i. (iii) Early and late genes are dispersed throughout the PBCV-1 genome. (iv) Viral gene probes often hybridize to mRNA transcripts that are 40-60\% larger than the gene itself, suggesting complex transcription patterns, e.g. the potassium ion channel protein (Kang et al., 2004a). In contrast, other genes produce mRNA transcripts of the expected size that are expressed either early or late, e.g. the RNase III gene (Zhang et al., 2003). No early or late PBCV1 gene promoters have been identified definitively because molecular techniques for manipulating virus genomes are presently unavailable. However, the 50 bases preceding most of the major ORFs are at least $70 \% \mathrm{~A}+\mathrm{T}$. In addition, highly conserved nucleotide sequences have been identified in the promoter regions of immediate-early genes (Kawasaki et al., 2004) and late genes (Kang et al., 2004a).

PBCV-1 does not encode a recognizable RNA polymerase or RNA polymerase subunit. Presently, it is unknown whether the infecting viral DNA moves to the nucleus or remains in the cytoplasm. It is presumed that the host RNA polymerase initiates viral transcription, possibly in collaboration with virus packaged transcription factors. Consistent with this possibility, PBCV-1 encodes at least four transcription factorlike proteins, TFIIB, TFIID, TFIIS and VLTF-2. However, it is not known if these proteins are active or packaged in the virion (Van Etten, 2003). PBCV-1 also encodes several gene prod- 
ucts involved in post-transcriptional modification, such as two enzymes involved in forming the mRNA cap structure, an RNA triphosphatase (Ho et al., 2001) and an RNA guanylyltransferase (Ho et al., 1996).

Recently, a PBCV-1-encoded 119-amino acid SET domaincontaining protein (referred to as VSET) was characterized (Manzur et al., 2003). A SET domain, originally identified in three Drosophila proteins (Suppressor of variegation, Enhancer of zeste and Trithorax, Tschiersch et al., 1994), is an evolutionarily conserved, 110-amino acid motif that is a component of larger multidomain proteins. SET domain-containing proteins methylate lysine residues in the N-termini of histones. Methylation is important in chromatin remodeling and transcriptional regulation (Trievel et al., 2002). vSET specifically di-methylates Lys 27 in histone 3 (Manzur et al., 2003). It is packaged in the PBCV-1 virion and this has led to the hypothesis that VSET is involved in repression of host transcription following PBCV-1 infection (K. L. Manzur et al., manuscript in preparation).

\section{DNA METHYLATION AND RESTRICTION}

Because chlorella virus genomes contain $5 \mathrm{mC}$ and $6 \mathrm{~mA}$ residues in specific sequences, it is not surprising that the viruses encode multiple cytosine and adenine DNA methyltransferases. However, it was a surprise to discover that $\sim 25 \%$ of the DNA methyltransferases have a companion DNA site-specific endonuclease (Nelson et al., 1998; Van Etten et al., 1991). Thus, chlorella virus-infected cells are the first non-prokaryotic source of type II DNA restriction endonucleases. Some virus-encoded restriction endonucleases have identical recognition and cleavage sites as bacterial type II endonucleases, e.g. PBCV-1-encoded R.CviAI (/GATC) (Xia et al., 1986) and others are heteroschizomers of bacterial endonucleases, such as R.CviAll (G/ATC) (Zhang et al., 1992). Still other endonucleases have novel recognition and cleavage sites, such as R.CviJ (RG/CY) encoded by virus IL3A (Xia et al., 1987). Two of the endonucleases encoded by viruses NYs-1 and NY-2A cleave one strand of dsDNA in a site-specific manner, Nt.CviPII cleaves /CCD and Nt.CviQXI cleaves R/AG sequences (Chan et al., 2004; Xia et al., 1988; Zhang et al., 1998). Like bacterial restriction endonucleases, the viral enzymes are inhibited by $5 \mathrm{mC}$ and/or $6 \mathrm{~mA}$ in their recognition sites. Interestingly, some viruses, such as NY-2A, encode as many as 18 DNA methyltransferases and at least two site-specific endonucleases (Zhang et al., 1998; J.L.V.E., unpublished results).

The chlorella virus restriction-modification ( $R-M)$ genes, like bacterial type II R-M genes, are located near each other, although the spacing and relative orientation of the two genes can vary. For example, the TAA stop codon of the M.CviAll gene from PBCV-1 overlaps the ATG translation start codon of the R.CviAll endonclease gene (Zhang et al., 1992). The R.CviJl endonuclease gene from virus IL-3A begins 18 nucleotides after the M.CviJl gene stop codon (Skowron et al., 1995). The biological function(s) of the chlorella virus-encoded DNA site-specific endonucleases and methyltransferases is unknown. Two possible functions have been suggested: (i) the endonucleases help degrade host DNA to provide deoxynucleotides for incorporation into virus DNA; (ii) the endonucleases prevent host cells from being infected by a second virus. Recent studies indicate that the restriction endonucleases, but not the corresponding DNA methyltransferases, are packaged in the PBCV-1 virion (D.D.D., I. Agarkova and J.L.V.E., manuscript in preparation).

\section{PROTEIN SYNTHESIS AND MODIFICATION}

PBCV-1 proteins are synthesized on cytoplasmic ribosomes and not organellar ribosomes because cycloheximide, but not chloramphenicol, inhibits viral replication (Skrdla et al., 1984). Some early virus proteins appear within $15 \mathrm{~min}$ p.i. (Zhang et al., 2003). How the virus takes over the host translational machinery and alters it to translate virus mRNAs is unknown.

PBCV-1 codon usage is biased to codons ending in $A /$ $U(63 \%)$ over those ending in G/C (37\%) (Schuster et al., 1990). This is consistent with the $40 \mathrm{~mol} \% \mathrm{G}+\mathrm{C}$ content of PBCV-1 DNA, whereas the host nuclear DNA is $67 \mathrm{~mol} \%$ $\mathrm{G}+\mathrm{C}$. Thus it is meaningful for PBCV-1 to encode 11 tRNA genes that tend to support the codon use bias. Other chlorella viruses encode as many as 16 tRNAs (Cho et al., 2002; Nishida et al., 1999). There is a strong correlation between abundance of the virus-encoded tRNAs and the virus codon usage (Nishida et al., 1999). The chlorella viruses are the first viruses known to encode a translation elongation factor (EF) (Yamada et al., 1993). The putative protein from PBCV1 has $\sim 45 \%$ amino acid identity to an EF-3 protein from fungi (Belfield and Tuite, 1993; Chakraburtty, 2001). The fungal EF-3 stimulates EF-1 $\alpha$-dependent binding of aminoacyl-tRNA to the A site of the ribosome. It is possible that the virus-encoded EF-3, in combination with the virus-encoded tRNAs, alters the host protein synthetic machinery to translate viral mRNAs preferentially.

Structural proteins of many viruses, such as herpesviruses, poxviruses and paramyxoviruses, as well as the chlorella viruses, are glycosylated. Typically, viral proteins are glycosylated by host-encoded glycosyltransferases located in the endoplasmic reticulum and Golgi and then transported to a host membrane (Doms et al., 1993; Olofsson and Hansen, 1998). Nascent viruses acquire the glycoprotein(s) and only become infectious by budding through the membrane, usually as they are released from the cell. Consequently, the glycan portion of virus glycoproteins is host specific.

However, glycosylation of PBCV-1 major capsid protein Vp54 differs from this paradigm. Accumulating evidence indicates that PBCV-1 encodes most, if not all, of the enzymes involved in constructing the complex oligosaccharide attached to Vp54 (summarized in Van Etten, 2003). Furthermore, the seven putative PBCV-1-encoded glycosyltransferases are predicted to be located in the cytoplasm, with one 
exception that is located in the plasma membrane (Graves et al., 2001; Que et al., 1994; Wang et al., 1993).

Besides the glycosyltransferases, PBCV-1 encodes several other putative proteins involved in post-translational modification, including a protein thiol oxidoreductase and a protein disulphide isomerase (Van Etten, 2003). An active prolyl 4hydroxylase (Eriksson et al., 1999) and seven active Ser/Thrprotein kinases are also encoded by PBCV-1 (P. Valbuzzi, J. R. Gurnon and J.L.V.E., manuscript in preparation).

\section{ION CHANNELS}

PBCV-1 encodes a 94-amino acid protein (KcV) that forms a functional $\mathrm{K}^{+}$-selective channel when expressed in Xenopus oocytes (Plugge et al., 2000), mammalian HEK 293 (Moroni et al., 2002) and $\mathrm{CHO}$ cells (Gazzarrini et al., 2003). Kcv was the first virus-encoded $\mathrm{K}^{+}$channel protein to be discovered, and it is the smallest protein known to form a functional twotransmembrane, one-pore $\mathrm{K}^{+}$channel. Genes encoding Kcv homologues from 40 additional chlorella viruses have 74 nucleotide changes, which produced 16 amino acid substitutions. These substitutions resulted in six new Kcv homologues with amino acid changes occurring in most of the functional domains of the proteins. The six new Kcv homologues form active $\mathrm{K}^{+}$channels in Xenopus oocytes with new properties, including altered current kinetics and inhibition by $\mathrm{Cs}^{+}$(Kang et al., 2004b). Correlations between amino acid substitutions and the properties displayed by these channels are used to guide site-directed mutations to identify key amino acids that confer specific properties to Kcv (Gazzarrini et al., 2004).

The discovery that the same compounds that inhibit Kcv potassium ion conductance in Xenopus oocytes also inhibit PBCV-1 plaque formation led to the conclusion that the Kcv channel is important for replication of the chlorella viruses. We hypothesize that $\mathrm{Kcv}$ is located in the internal membrane of the virions and that when the virus membrane fuses with the host membrane during infection, $\mathrm{Kcv}$ is activated. Consistent with this hypothesis, membrane depolarization occurs immediately after adding viruses to the chlorella host cells and the depolarization displays the same sensitivity to inhibitors as Kcv conductance in Xenopus oocytes (Mehmel et al., 2003; F. Frohns et al., manuscript in preparation).

PBCV-1 also encodes two adjacent but divergent ORFs (a162I and a163r) that resemble ligand-gated ion channel proteins (Kang et al., 2003). The A162L and A163R proteins have a predicted three-transmembrane, one-pore topology structure that is typical of glutamate receptors (Dingledine et al., 1999). Glutamate receptors function as glutamateactivated ion channels which mediate cation flux $\left(\mathrm{K}^{+}, \mathrm{Na}^{+}\right.$, $\mathrm{Ca}^{2+}$ ) across membranes. However, efforts to express these two genes in Xenopus oocytes have been unsuccessful.

Ongoing chlorella virus genome sequencing projects indicate that other channel-like proteins exist in the chlorella viruses, including an aquaglyceroporin channel in the Pbi virus MT325 (M. Kang, A. Moroni and J.L.V.E., unpublished data).

\section{HOST CELL SURFACE CHANGES}

Chlorella viruses are the only viruses known to encode enzymes involved in the biosynthesis of the linear polysaccharide hyaluronan (also called hyaluronic acid). Hyaluronan, a ubiquitous constituent of the extracellular matrix in vertebrates, is composed of $\sim 20000$ alternating $\beta$-1,4-glucuronic acid and $\beta-1,3-\mathrm{N}$-acetylglucosamine residues (DeAngelis, 1999). PBCV-1 contains genes encoding hyaluronan synthase (HAS) (DeAngelis et al., 1997) and two other enzymes required for the biosynthesis of hyaluronan precursors, glutamine: fructose-6-phosphate amidotransferase and UDP-glucose dehydrogenase (Landstein et al., 1998). All three genes are expressed early during virus infection and this finding led to the discovery that hyaluronan lyasesensitive, hair-like fibers begin to accumulate on the surface of virus-infected host cells by 15 min p.i. By $240 \mathrm{~min}$ p.i., the cells are covered with a dense fibrous hyaluronan network (Graves et al., 1999).

The biological function(s) of the extracellular hyaluronan is unknown. We have considered three possibilities. (i) The polysaccharide prevents uptake of virus-infected chlorella by the paramecium. Presumably, such infected algae would lyse inside the paramecium and released virions would be digested by the protozoan. This scenario would be detrimental to virus survival. (ii) The viruses have another host that acquires the virus by taking up the hyaluronan-covered algae. (iii) Virus-infected cells aggregate, presumably due to the extracellular polysaccharide. This aggregation, which could trap uninfected cells, might aid the virus in finding its next host.

A complicating factor in understanding the biological importance of hyaluronan, however, is the discovery that not all chlorella viruses have an has gene. Some chlorella virus isolates encode a functional chitin synthase (CHS) instead of HAS and produce chitin fibres on the external surface of the infected cells (Kawasaki et al., 2002). A few viruses encode both has and chs; cells infected with these viruses accumulate both hyaluronan and chitin on their surfaces. Finally, some viruses apparently lack both genes (Graves et al., 1999).

\section{THE NATURAL HISTORY OF CHLORELLA VIRUSES}

The natural history of the chlorella viruses is poorly understood. The hosts for the NC64A and Pbi viruses, Chlorella NC64A and Chlorella Pbi, are resistant to virus infection when they are in a symbiotic relationship and can only be infected when they are separated from paramecium (Kawakami and Kawakami, 1978; Reisser et al., 1991). It is unknown whether NC64A and Pbi viruses replicate exclusively in paramecium chlorella, and it is also unknown if the symbiotic chlorella exists free of paramecium in natural environments (Van Etten, 2003). However, the observation that titers as high as $100000 \mathrm{PFU} / \mathrm{mL}$ can occasionally be obtained from indigenous water and that green paramecia are rare in nature suggest that the chlorella viruses may have another host(s). 
Usually solar radiation damages viral DNA and quickly inactivates viruses (e.g. Wilhelm et al., 1998). However, the ubiquitous nature of the chlorella viruses indicates that they have adapted to solar radiation, possibly by having access to two independent DNA repair systems (Furuta et al., 1997). (i) PBCV-1 encodes a pyrimidine dimer-specific glycosylase that is involved in UV-induced thymidine dimer repair. (ii) PBCV1 also uses the host photolyase to repair UV-induced thymidine dimers. The combined activities of these repair systems may enable PBCV-1 to survive under a range of environmental conditions and to withstand substantial solar radiation. Furthermore, PBCV-1 encodes a functional $\mathrm{Cu} / \mathrm{Zn}$ superoxide dismutase (M.K. and J.L.V.E., unpublished results) that may help protect DNA from reactive oxygen species.

\section{RELATIONSHIPS TO OTHER VIRUSES}

Most known algal viruses are icosahedral in shape and contain dsDNA genomes that range in size from 100 to $560 \mathrm{~kb}$. Based on these properties and DNA polymerase gene sequence information (Chen and Suttle, 1996; Lee et al., 1998), the viruses are assigned to the virus family Phycodnaviridae, which presently consists of six genera: Chlorovirus, Coccolithovirus, Prasinovirus, Primnesiovirus, Phaeovirus, and Raphidovirus (Wilson et al., 2004).

Ectocarpus siliculosus virus (EsV-1), a member of the genus Phaeovirus that infects the marine filamentous brown alga E. siliculosus, was the second phycodnavirus to have its genome sequenced (Delaroque et al., 2001). The EsV-1 335$\mathrm{kb}$ genome is slightly larger than the PBCV-1 genome and is predicted to contain 231 protein-encoding genes. The virus initiates its life cycle by infecting free-living, wall-less gametes (zoospores) of the host, integrates its DNA into the host genome and begins a lysogenic phase. The virus genome remains latent in vegetative cells and only forms infectious virions in the reproductive cells of the host (gametangia and/or sporangia) (Mueller et al., 1998).

Other algal viruses have been studied primarily because they are very important in regulating phytoplankton communities in marine environments. Viruses were associated with the collapse of a brown tide caused by Aureococcus anophagefferens (Sieburth et al., 1988) and a red tide caused by Heterosigma akashiwo (Nagasaki et al., 1994, 1999). Higher than $25 \%$ algal mortality was attributed to virus lysis during the collapse of a toxic algal bloom caused by Emiliana huxleyi (Bratbak et al., 1993). Four large lytic viruses isolated from the marine algae E. huxleyi (EhV), Phaeocytis pochetii (PpV), Chrysochromulina ericina (CeV-01B) and Pyramimonas orientalis (PoV-01B) have 412-, 485-, 510- and 560-kb genomes, respectively (Castberg et al., 2002; Jacobsen et al., 1996; Sandaa et al., 2002).

Comparative analysis of protein sequences encoded by poxviruses, African swine fever virus, iridoviruses and phycodnaviruses, which are collectively referred to as nucleocytoplasmic large DNA viruses (NCLDVs), identified nine gene products that are shared by all of these viruses and 19 more gene products that are present in at least three of these viral families (lyer et al., 2001). Cladistic analysis using the gene products shared by at least two viral families as evolutionary characters led lyer et al. (2001) to propose that viruses in all four families arose from a common ancestor. The recently described 1200-kb mimivirus (La Scola et al., 2003; Raoult et al., 2004) encodes 42 putative gene products that are shared by at least two members of the NCLDV families, indicating that this virus is also related to the NCLDVs.

The biological significance of the algal viruses was exemplified by the discovery that seawater contains more than $10^{7}$ virus-like particles per milliliter. This population consists of both bacterial and algal viruses (Bergh et al., 1989; Proctor and Fuhrman, 1990). These viruses impact both the microbial composition and diversity (Bratbak et al., 1996), as well as nutrient cycling in native waters (Wilhelm and Suttle, 1999). Thus, algal viruses contribute significantly to the aquatic food webs and are involved in modulating atmospheric gases (Wommack and Colwell, 2000).

\section{CHLORELLA VIRUSES ARE PROBABLY ANCIENT VIRUSES}

Accumulating evidence indicates that the phycodnaviruses and their genes have a long evolutionary history, possibly beginning at the time eukaryotes separated from prokaryotes (over 3 billion years ago) (Benson et al., 2004; Falkowski et al., 2004; Villarreal, 1999). (i) Phylogenic analyses of DNA polymerases place the phycodnavirus enzymes near the root of all eukaryotic $\delta$-DNA polymerases (Villarreal and DePhilippis, 2000; Villarreal, 1999). (ii) Phylogenic analyses of other PBCV-1-encoded proteins often place the proteins near the root of their eukaryotic counterparts, such as the $\mathrm{K}^{+}$channel protein Kcv (Plugge et al., 2000) and ornithine decarboxylase (Morehead et al., 2002). (iii) Even though PBCV-1 encodes both prokaryotic- and eukaryotic-like proteins, the $40 \mathrm{~mol} \% \mathrm{G}+\mathrm{C}$ content is fairly uniform throughout the genome. This pattern suggests that most of the genes have existed together in the virus for a long time. (iv) The major coat protein from several dsDNA viruses that infect all three domains of life are structurally similar, suggesting these viruses have a common ancestor (Benson et al., 2004). PBCV-1 is included in this group of viruses.

Thus studies on the phycodnaviruses may reveal information on the evolution of genes and genomes. Finally, some evolutionary biologists have suggested that large dsDNA viruses, like the chlorella viruses, may be the origin of the nucleus in eukaryotic cells (e.g. Bell, 2001; Pennisi, 2004).

\section{CONCLUSIONS}

Although the chlorella viruses have existed in nature for a very long time, they are relatively new to virologists. However, even with our limited knowledge, research on chlorella viruses is contributing scientific and economic benefits: 
1. Chlorella viruses, which encode 375 or more ORFs, are sources of new and unexpected genes. These genes not only encode commercially important enzymes such as DNA restriction endonucleases, but many viral enzymes are the smallest in their class. Consequently, these proteins serve as biochemical models for mechanistic and structural studies.

2. The viruses are a novel source of genes and genetic elements that can be used to engineer other organisms. Examples include: (a) promoter elements cloned from chlorella viruses function well in both monocots and dicots of higher plants, as well as bacteria (Mitra and Higgins, 1994; Mitra et al., 1994); and (b) expression of the PBCV1 pyrimidine dimer-specific glycosylase-encoding gene in a baculovirus increases its resistance to UV inactivation (Patrik et al., 2003).

3. Chlorella viruses contain a mosaic of prokaryotic and eukaryotic genes and may be related to the last common ancestor of these two kingdoms. Thus, the chlorella viruses and their genes may have a long evolutionary history. Therefore, studies on these viruses may reveal interesting aspects about the evolution of genes and genomes.

4. Algal viruses play an important role in regulating phytoplankton communities in aqueous environments. They are a potential agent for the biological control of algal blooms, including "red tides" and "brown tides." More information about chlorella viruses is available on the "World of Chlorella Viruses" website at http://plantpath.unl.edu/facilities/Virology/.

\section{ACKNOWLEDGMENTS}

Research at our laboratory was supported in part by Public Health service Grant GM32441 from the National Institute of General Medical Sciences.

\section{REFERENCES}

Belfield, G.P. and Tuite, M.F. (1993) Translation elongation factor 3: a fungus-specific translation factor? Mol. Microbiol. 9, 411-418.

Bell, P.J.L. (2001) Viral eukaryogenesis: was the ancestor of the nucleus a complex DNA virus? J. Mol. Evol. 53, 251-256.

Benson, S.D., Bamford, J.K.H., Bamford, D.H. and Burnett, R.M. (2004) Does common architecture reveal a virus lineage spanning all three domains of life? Mol. Cell, 16, 673-685.

Bergh, O., Borsheim, K.Y., Bratbak, G. and Heldal, M. (1989) High abundance of viruses found in aquatic environments. Nature, 340, 467-468.

Bratbak, G., Thingstad, T.F. and Heldal, M. (1993) Viral mortality of marine alga Emiliania huxleyi. Haptophyceae and termination of algal blooms. Mar. Ecol. Prog. Series, 93, 352-356.

Bratbak, G., Wilson, W. and Heldal, M. (1996) Viral control of Emiliania huxleyi? J. Mar. Systems, 9, 75-81.

Castberg, T., Thyrhaug, R., Larson, A., Sandaa, R.A. and Heldal, M. (2002) Isolation and characterization of a virus that infects Emiliania huxleyi (Haptophyta). J. Phycol. 38, 767-774.
Chakraburtty, K. (2001) Translational regulation by ABC system. Res. Microbiol. 152, 391-399.

Chan, S.-H., Zhu, Z., Van Etten, J.L. and Xu, S.-Y. (2004) Cloning of CviPII nicking and modification system from chlorella virus NYs-1 and application of Nt.CviPII in random DNA amplification. Nucleic Acids Res. 32, 6187-6199.

Chen, F. and Suttle, C.A. (1996) Evolutionary relationships among large double-stranded NDA viruses that infect microalgae and other organisms as inferred from DNA polymerase genes. Virology, 219, 170-178.

Cho, H.-H., Park. H.-H., Kim, J.-O. and Choi, T.-J. (2002) Isolation and characterization of chlorella viruses from the freshwater sources in Korea. Molecules Cells, 14, 168-176.

DeAngelis, P.L. (1999) Hyaluronan synthase: fascinating glycosyltransferases from vertebrates, bacterial pathogens, and algal viruses. Cell Mol. Life Sci. 56, 670-682.

DeAngelis, P.L., Jing, W., Graves, M.V., Burbank, D.E. and Van Etten, J.L. (1997) Hyaluronan synthase of chlorella virus PBCV1. Science, 278, 1800-1803.

Delaroque, N., Mueler, D.G., Bothe, G., Pohl, T., Knippers, R. and Boland, W. (2001) The complete DNA sequence of the Ectocarpus siliculosus virus genome. Virology, 287, 112-132.

Dingledine, R., Borges, K., Bowie, D. and Traynelis, S.F. (1999) The glutamate receptor ion channels. Pharmacol. Rev. 51, 7-61.

Doms, R.W., Lamb, R.A., Rose, J.K. and Helenius, A. (1993) Folding and assembly of viral membrane proteins. Virology, 193, 545-562.

Eriksson, M., Myllyharju, J., Tu, H., Hellman, M. and Kivirikko, K.I. (1999) Evidence for 4-hydroxyproline in viral proteins: characterization of a viral prolyl 4 hydroxylase and its peptide substrates. J. Biol. Chem. 274, 22131-22134.

Falkowski, P.G., Katz, M.E., Knoll, A.H., Quigg, A., Raven, J.A., Schofield, O. and Taylor, F.J.R. (2004) The evolution of modern eukaryotic phytoplankton. Science, 305, 354-360.

Fortune, J.M., Lavrukhin, O.V., Gurnon, J.R., Van Etten, J.L., Lloyd, R.S. and Osheroff, N. (2001) Topoisomerase II from chlorella virus PBCV-1 has an exceptionally high DNA cleavage activity. J. Biol. Chem. 276, 24401-24408.

Furuta, M., Schrader, J.O., Schrader, S.H., Kokjohn, T.A., Nyaga, S., McCullough, A.K., Lloyd, R.S., Burbank, D.E. and Van Etten, J.L. (1997) Chlorella virus PBCV-1 encodes a homologue of the bacteriophage T4 DNA repair gene DenV. Appl. Environ. Microbiol. 63, 1551-1556.

Gazzarrini, S., Kang, M., Van Etten, J.L., Tayefeh, S., Kast, S.M., DiFrancesco, D., Thiel, G. and Moroni, A. (2004) Long distance interactions within the potassium channel pore are revealed by molecular diversity of viral proteins. J. Biol. Chem. 279, 28443-28449.

Gazzarrini, S., Severino, M., Lombardi, M., Morandi, M., DiFrancesco, D., Van Etten, J.L., Thiel, G. and Moroni, A. (2003) The viral potassium channel Kcv: structural and functional features. FEBS Lett. 552, 12-16.

Girton, L.E. and Van Etten, J.L. (1987) Restriction site map of the chlorella virus PBCV-1 genome. Plant Mol. Biol. 9, 247-257.

Grabherr, R., Strasser, P. and Van Etten, J.L. (1992) The DNA polymerase gene from chlorella viruses PBCV-1 and NY-2A contains an intron with nuclear splicing sequences. Virology, 188, $721-731$.

Graves, M.V., Bernadt, C.T., Cerny, R. and Van Etten, J.L. (2001) Molecular and genetic evidence for a virus-encoded glycosyltransferase involved in protein glycosylation. Virology, 285, 332-345. 
Graves, M.V., Burbank, D.E., Roth, R., Heuser, J., DeAngelis, P.L. and Van Etten, J.L. (1999) Hyaluronan synthesis in virus PBCV1 infected chlorella-like green algae. Virology, 257, 15-23.

Hakansson, K. and Wigley, D.B. (1998) Structure of a complex between a cap analogue and mRNA guanylyltransferase demonstrates the structural chemistry of RNA capping. Proc. Natl Acad. Sci. USA, 95, 1505-1510.

Hiramatsu, S., Fujie, M., Usami, S., Sakai, K. and Yamada, T. (2000) Two catalytic domains of chlorella virus CVK2 chitinase. J. Biosci. Bioeng. 89, 252-257.

Hiramatsu, S., Ishihara, M., Fujie, M., Usami, S. and Yamada, T. (1999) Expression of a chitinase gene and lysis of the host cell wall during chlorella virus CVK2 infection. Virology, 260, 308-315.

Ho, C.K., Gong, C. and Shuman, S. (2001) RNA triphosphatase component of the mRNA capping apparatus of Paramecium bursaria Chlorella virus 1. J. Virol. 75, 1744-1750.

Ho, C.K., Van Etten, J.L. and Shuman, S. (1996) Expression and characterization of an RNA capping enzyme encoded by chlorella virus PBCV-1. J. Virol. 70, 6658-6664.

Ho, C.K., Van Etten, J.L. and Shuman, S. (1997) Characterization of an ATP-dependent DNA ligase encoded by chlorella virus PBCV-1. J. Virol. 71, 1931-1937.

lyer, L.M., Aravind, L. and Koonin, E.V. (2001) Common origin of four diverse families of large eukaryotic DNA viruses. J. Virol. 75, 11720-11734.

Jacobsen, A., Bratbak, G. and Heldal, M. (1996) isolation and characterization of a virus infecting Phaeocrystis pouchetii Prymnesiophyceae. J. Phycol. 32, 923-927.

Kang, M., Graves, M.V., Mehmel, M., Moroni, A., Gazzarrini, S., Thiel, G., Gurnon, J.R. and Van Etten, J.L. (2004a) Genetic diversity in chlorella viruses flanking $\mathrm{kcv}$, a gene that encodes a potassium ion channel protein. Virology, 326, 150-159.

Kang, M., Moroni, A., Gazzarrini, S., DiFrancesco, D., Thiel, G., Severino, M. and Van Etten, J.L. (2004b) Small potassium ion channel proteins encoded by chlorella viruses. Proc. Natl Acad. Sci. USA, 101, 5318-5324.

Kang, M., Moroni, A., Gazzarrini, S. and Van Etten, J.L. (2003) Are chlorella viruses a rich source of ion channel genes? FEBS Lett. 552, 2-6.

Kapaun, E., Loose, E. and Reisser, W. (1992) Cell composition of virus-sensitive symbiotic chlorella species. Phytochemistry, 31, 3103-3104.

Kapaun, E. and Reisser, W. (1995) A chitin-like glycan in the cell wall of a Chlorella sp. Chlorococales, Chlorophyceae. Planta, 197, 577-582.

Kawakami, H. and Kawakami, N. (1978) Behavior of a virus in a symbiotic system Paramecium bursaria-zoochlorella. J. Protozool. 25, 217-225.

Kawasaki, T., Tanaka, M., Fujie, M., Usami, S., Sakai, K. and Yamada, T. (2002) Chitin synthesis in Chlorovirus CVK2 infected chlorella cells. Virology, 302, 123-131.

Kawasaki, T., Tanaka, M., Fujie, M., Usami, S. and Yamada, T. (2004) Immediate early genes expressed in chlorovirus infections. Virology, 318, 214-223.

Kutish, G.F., Li, Y., Lu, Z., Furuta, M., Rock, D.M. and Van Etten, J.L. (1996) Analysis of $76 \mathrm{~kb}$ of the chlorella virus PBCV-1 330-kb genome: map positions 182-258. Virology, 223, 303-317.

La Scola, B., Audic, S., Robert, C., Jungang, L., de Lamballerie, X., Drancourt, M., Birtles, R., Claverie, J.-M. and Raoult, D. (2003) A giant virus in amoebae. Science, 299, 2033.

Landstein, D., Graves, M.V., Burbank, D.E., DeAngelis, P.L. and Van
Etten, J.L. (1998) Chlorella virus PBCV-1 encodes functional glutamine: fructose-6-phosphate amidotransferase and UDPglucose dehydrogenase enzymes. Virology, 250, 388-396.

Lavrukhin, O.V., Fortune, J.M., Wood, T.G., Burbank, D.E., Van Etten, J.L., Osheroff, N. and Lloyd, R.S. (2000) Topoisomerase II from chlorella virus PBCV-1. Characterization of the smallest known type II topoisomerase. J. Biol. Chem. 275, 6915-6921.

Lee, A.M., Ivey, R.G. and Meints, R.H. (1998) The DNA polymerase gene of a brown algal virus: structure and phylogeny. J. Phycol. 34, 608-615.

Li, Y., Lu, Z., Burbank, D.E., Kutish, G.F., Rock, D.L. and Van Etten, J.L. (1995) Analysis of $43 \mathrm{~kb}$ of the chlorella virus PBCV-1 330kb genome: map position 45-88. Virology, 212, 134-150.

Li, Y., Lu, Z., Sun, L., Ropp, S., Kutish, G.F., Rock, D.L. and Van Etten, J.L. (1997) Analysis of $74 \mathrm{~kb}$ of DNA located at the right end of the $330 \mathrm{~kb}$ chlorella virus PBCV-1 genome. Virology, 237, 360-377.

Lu, Z., Li, Y., Que, Q., Kutish, G.F., Rock, D.L. and Van Etten, J.L. (1996) Analysis of $94 \mathrm{~kb}$ of the chlorella virus PBCV-1 330-kb genome: map position 88-182. Virology, 216, 102-123.

Lu, Z., Li, Y., Zhang, Y., Kutish, G.F., Rock, D.L. and Van Etten, J.L. (1995) Analysis of $45 \mathrm{~kb}$ of DNA located at the left end of the $330 \mathrm{~kb}$ chlorella virus PBCV-1 genome. Virology, 206, 339-352.

Manzur, K.L., Farooq, A., Zeng, L., Plotnikov, O., Koch, A.W., Sachchidanand and Zhou, M.-M. (2003) A dimeric viral SET domain methyltransferase specific to Lys27 of histone H3. Nat. Struct. Biol. 10, 187-196.

Mehmel, M., Rothermel, M., Meckel, T., Van Etten, J.L., Moroni, A. and Thiel, G. (2003) Possible function for virus encoded $\mathrm{K}^{+}$ channel Kcv in the replication of chlorella virus PBCV-1. FEBS Lett. 552, 7-11.

Meints, R.H., Lee, K., Burbank, D.E. and Van Etten, J.L. (1984) Infection of a chlorella-like alga with the virus, PBCV-1: ultrastructural studies. Virology, 138, 341-346.

Meints, R.H., Lee, K. and Van Etten, J.L. (1986) Assembly site of the virus PBCV-1 in chlorella-like green alga: ultrastructural studies. Virology, 154, 240-245.

Mitra, A. and Higgins, D.W. (1994) The chlorella virus adenine methyltransferase gene promoter is a strong promoter in plants. Plant Mol. Biol. 26, 85-93.

Mitra, A., Higgins, D.W. and Rohe, N.J. (1994) A chlorella virus gene promoter functions as a strong promoter both in plants and bacteria. Biochem. Biophys. Res. Commun. 204, 189-194.

Morehead, T.J., Gurnon, J.R., Adams, B., Nickerson, K.W., Fitzgerald, L.A. and Van Etten, J.L. (2002) Ornithine decarboxylase encoded by chlorella virus PBCV-1. Virology, 301, 165-175.

Moroni, A., Viscomi, C., Sangiorgio, V., Pagliuca, C., Meckel, T., Horvath, S.F., Gazzarrini, S., Valbuzzi, P., Van Etten, J.L., DiFrancesco, D. and Thiel, G. (2002) The short N-terminus is required for functional expression of the virus-encoded miniature $\mathrm{K}^{+}$channel Kcv. FEBS Lett. 530, 65-69.

Mueller, D.G., Kapp, M. and Knippers, R. (1998) Viruses in marine brown algae. Adv. Virus Res. 50, 49-67.

Nagasaki, K., Ando, M., Itakura, S., Imai, I. and Ishida, Y. (1994) Virus-like particles in Heterosigma akashiwo Raphidophyceae: a possible red tide disintegration mechanism. Mar. Biol. 119, 307-312.

Nagasaki, K., Tarutani, K. and Yamaguchi, M. (1999) Growth characteristics of Heterosigma akashiwo virus and its possible use as a microbiological agent for red tide control. Appl. Environ. Microbiol. 65, 898-902. 
Nandhagopal, N., Simpson, A., Gurnon, J.R., Yan, X., Baker, T.S., Graves, M.V., Van Etten, J.L. and Rossmann, M.D. (2002) The structure and evolution of the major capsid protein of a large, lipid-containing DNA virus. Proc. Natl Acad. Sci. USA, 99, 14758-14763.

Nelson, M., Burbank, D.E. and Van Etten, J.L. (1998) Chlorella viruses encode multiple DNA methyltransferases. Biol. Chem. 379, 423-428.

Nishida, K., Kawasaki, T., Fujie, M., Usami, S. and Yamada, T. (1999) Aminoacylation of tRNAs encoded by chlorella virus CVK2. Virology, 263, 220-229.

Olofsson, S. and Hansen, J.E.S. (1998) Host cell glycosylation of viral glycoproteins: a battlefield for host defence and viral resistance. Scand. J. Infect. Dis. 30, 435-440.

Patrik, D.T., Iseli, A., Montelone, B.A., Van Etten, J.L. and Clem, R.J. (2003) Improving baculovirus resistance to UV inactivation: increased virulence resulting from expression of a DNA repair enzyme. J. Invert. Pathol. 82, 50-56.

Pennisi, E. (2004) The birth of the nucleus. Science, 305, $766-768$.

Plugge, B., Gazzarrini, S., Nelson, M., Cerana, R., Van Etten, J.L., Derst, C., DiFrancesco, D., Moroni, A. and Thiel, G. (2000) A potassium channel protein encoded by chlorella virus PBCV-1. Science, 287, 1641-1644.

Proctor, L.M. and Fuhrman, J.A. (1990) Viral mortality of marine bacteria and cyanobacteria. Nature, 343, 60-62.

Que, Q., Li, Y., Wang, I.-N., Lane, L.C., Channey, W.G. and Van Etten, J.L. (1994) Protein glycosylation and myristoylation in chlorella virus PBCV-1 and its antigenic variants. Virology, 203, 320-327.

Raoult, D., Audic, S., Robert, C., Abergel, C., Renesto, P., Ogata, H., La Scola, B., Suzan, M. and Claverie, J.-M. (2004) The 1.2megabase genome sequence of mimivirus. Science, 306, 1344-1350.

Reisser, W., Burbank, D.E., Meints, R.H., Becker, B. and Van Etten, J.L. (1991) Viruses distinguish symbiotic Chlorella spp. of Paramecium bursaria. Endocyobiosis Cell Res. 7, 245-251.

Reisser, W., Burbank, D.E., Meints, S.M., Meints, R.H., Becker, B. and Van Etten, J.L. (1988) A comparison of viruses infecting two different chlorella-like green algae. Virology, 167, 143-149.

Rohozinski, J., Girton, L.E. and Van Etten, J.L. (1989) Chlorella viruses contain linear nonpermuted double-stranded DNA genomes with covalently closed hairpin ends. Virology, 168, 364-369.

Sandaa, R.A., Heldal, M., Castberg, T., Thyrhaug, R. and Bratbak, G. (2002) Isolation and characterization of two viruses with large genome size infecting Chrysochromulina ericina (Prymnesiophyceae) and Pyramimonos orientalis (Prasinophyceae). Virology, 290, 272-280.

Schuster, A.M., Girton, L., Burbank, D.E. and Van Etten, J.L. (1986) Infection of a chlorella-like alga with virus PBCV-1: transcriptional studies. Virology, 148, 181-189.

Schuster, A.M., Graves, M.V., Korth, K., Ziegelbein, M., Brumbough, J., Grone, D. and Meints, R.H. (1990) Transcription and sequence studies of a 4.3-kb fragment from a dsDNA eukaryotic algal virus. Virology, 176, 515-523.

Shihra, I. and Krauss, R.W. (1965) Chlorella Physiology and Taxonomy of Forty-One Isolates. College Park, MD: University of Maryland Press.

Sieburth, J.M., Johnson, P.W. and Hargraves, P.E. (1998) Ultrastructure and ecology of Aureococcus anophagofferens gen. et. sp. nov. Chrysophyceae: the dominant picoplankton during a bloom in Narragansett Bay, Rhode Island, summer 1985. J. Phycol. 24, 416-425.

Skowron, P.M., Swaminathan, N., McMaster, K., George, D., Van Etten, J.L. and Mead, D.A. (1995) Cloning and applications of two/three-base restriction endonuclease R.CviJl from IL-3A virus infected chlorella. Gene, 157, 34-41.

Skrdla, M.P., Burbank, D.E., Xia, Y., Meints, R.H. and Van Etten, J.L. (1984) Structure proteins and lipids in a virus, PBCV-1, which replicates in a chlorella-like alga. Virology, 135, 308-315.

Strasser, P., Zhang, Y., Rohozinski, J. and Van Etten, J.L. (1991) The termini of the chlorella virus PBCV-1 genome are identical 2.2-kbp inverted repeats. Virology, 180, 763-769.

Suda, K., Tanji, Y., Hori, K. and Unno, H. (1999) Evidence for a novel chlorella virus encoded alginate lyase. FEMS Microbiol. Lett. 180, 45-53.

Sugimoto, I., Hiramatsu, S., Murakami, D., Fujie, M., Usami, S. and Yamada, T. (2000) Algal-lytic activities encoded by chlorella virus CVK2. Virology, 277, 119-126.

Sun, L., Adams, B., Gurnon, J.R., Ye, Y. and Van Etten, J.L. (1999) Characterization of two chitinase genes and one chitosanase genes encoded by chlorella virus PBCV-1. Virology, 263, 376-387.

Sun, L., Gurnon, J.R., Adams, B., Graves, M.V. and Van Etten, J.L. (2000) Characterization of a $\beta$-1,3-glucanase encoded by chlorella virus PBCV-1. Virology, 276, 27-36.

Trievel, R.C., Beach, B.M., Dirk, L.M.A., Houtz, R.L. and Hurley, J.H. (2002) Structure and catalytic mechanism of a SET domain protein methyltransferase. Cell, 111, 91-103.

Tschiersch, B., Hofmann, A., Krauss, V., Dorn, R., Korge, G. and Reuter, G. (1994) The protein encoded by the Drosophila position-effect variegation suppressor gene Su (var) 3-9 combines domains of antagonistic regulators of homeotic gene complexes. EMBO J. 13, 3822-3831.

Van Etten, J.L. (2003) Unusual life style of giant chlorella viruses. Annu. Rev. Genet. 37, 153-195.

Van Etten, J.L., Burbank, D.E., Joshi, J. and Meints, R.H. (1984) DNA sythesis in a chlorella-like alga following infection with the virus PBCV-1. Virology, 134, 443-449.

Van Etten, J.L., Burbank, D.E., Kuczmarski, D. and Meints, R.H. (1983a) Virus infection of culturable chlorella-like algae and development of a plaque assay. Science, 219, 994-996.

Van Etten, J.L., Burbank, D.E., Schuster, A.M. and Meints, R.H. (1985a) Lytic viruses infecting a chlorella-like alga. Virology, 140, 135-143.

Van Etten, J.L., Burbank, D.E., Xia, Y. and Meints, R.H. (1983b) Growth cycle of a virus PBCV-1 that infects chlorella-like algae. Virology, 126, 117-125.

Van Etten, J.L., Lane, L.C. and Meints, R.H. (1991) Viruses and virus-like particles of eukaryotic algae. Microbiol. Rev. 55, 586-620.

Van Etten, J.L., Van Etten, C.H., Johnson, J.K. and Burbank, D.E. (1985b) A survey for viruses from freshwater that infect a eukaryotic chlorella-like green alga. Appl. Environ. Microbiol. 49, 1326-1328.

Villarreal, L.P. (1999) DNA viruses: their influence on host evolution. In Origin and Evolution of Viruses (Domingo, E., Webster, R., Holand, J.J. and Pickett, T.. London: Academic Press, pp. 391-410.

Villarreal, L.P. and Dephilippis, V.R. (2000) A hypothesis for DNA viruses as the origin of eukaryotic replication proteins. J. Virol. 74, 7079-7084. 
Wang, I.-N., Li, Y., Que, Q., Bhattachayya, M., Lane, L.C., Channey, W.G. and Van Etten, J.L. (1993) Evidence for virus-encoded glycosylation specificity. Proc. Natl Acad. Sci. USA, 90, 3840-3844.

Warbrick, E. (2000) The puzzle of PCNA's many partners. Bioessays, 22, 997-1006.

Wilhelm, S.W. and Suttle, C.A. (1999) Viruses and nutrient cycles in the sea. Bioscience, 49, 781-788.

Wilhelm, S.W., Weinbauer, M.G., Suttle, C.A. and Jeffrey, W.H. (1998) The role of sunlight in the removal and repair of viruses in the sea. Limnol. Oceanogr. 43, 586-592.

Wilson, W.H., Van Etten, J.L., Schroeder, D.S., Nagasaki, K., Brussaard, C., Delaroque, N., Bratbak, G. and Suttle, C. (2004) Phycodnaviridae. In Virus Taxonomy, VIIIth Report of the ICTV (Fauquet, C.M., Mayo, M.A., Maniloff, J., Desselberger, U. and Ball, L.A.. London: Elsevier/Academic Press, pp. $163-175$.

Wommack, K.E. and Colwell, R.R. (2000) Virioplankton: viruses in aquatic ecosystem. Microbiol. Mol. Biol. Rev. 64, 69-114.

Xia, Y., Burbank, D.E., Uher, L., Rabussay, D. and Van Etten, J.L. (1986) Restriction enzyme activity induced by PBCV-1 virus infection of a chlorella-like green alga. Mol. Cell Biol. 6, 1430-1439.

Xia, Y., Burbank, D.E., Uher, L., Rabussay, D. and Van Etten, J.L. (1987) IL-3A virus infection of a chlorella-like green alga induces a DNA restriction endonuclease with novel sequence specificity. Nucleic Acids Res. 15, 6075-6090.

Xia, Y., Morgan, R., Schildkraut, I. and Van Etten, J.L. (1988) A sitespecific single strand endonuclease activity induced by NYs-1 virus infection of a chlorella-like green alga. Nucleic Acids Res. 16, 9477-9487.
Yamada, T., Fukuda, T., Tamura, K., Furukawa, S. and Songsri, P. (1993) Expression of the gene encoding a translational elongation factor 3 homolog of chlorella virus CVK2. Virology, 197, $742-750$.

Yamada, T., Higashiyama, T. and Fukuda, T. (1991) Screening of natural waters for viruses which infect chlorella cells. Appl. Environ. Microbiol. 57, 3433-3437.

Yamada, T., Tamura, K., Aimi, T. and Songsri, P. (1994) Self-splicing group I introns in eukaryotic viruses. Nucleic Acids Res. 22, 2532-2537.

Yan, X., Olson, N.H., Van Etten, J.L., Bergoin, M., Rossmann, M.G. and Baker, T.S. (2000) Structure and assembly of large, lipidcontaining, dsDNA viruses. Nat. Struct. Biol. 7, 101-103.

Zhang, Y., Burbank, D.E. and Van Etten, J.L. (1988) Chlorella viruses isolated in China. Appl. Environ. Microbiol. 54, 2170-2173.

Zhang, Y., Calin-Jageman, I., Gurnon, J.R., Choi, T., Adams, B., Nicholson, A.W. and Van Etten, J.L. (2003) Characterization of a chlorella virus encoded ribonuclease III. Virology, 317, $73-78$.

Zhang, Y., Nelson, M., Nietfeldt, J.W., Burbank, D.E. and Van Etten, J.L. (1992) Characterization of chlorella virus PBCV-1 CviAll restriction and modification system. Nucleic Acids Res. 20, 5351-5356.

Zhang, Y., Nelson, M., Nietfeldt, J.W., Xia, Y., Burbank, D.E., Ropp, S. and Van Etten, J.L. (1998) Chlorella virus NY-2A encodes at least twelve DNA endonuclease/methyltransferase genes. Virology, 240, 366-375.

Zhang, Y., Strasser, P., Grabherr, R. and Van Etten, J.L. (1994) Hairpin loop structure at the termini of the chlorella virus PBCV-1 genome. Virology, 202, 1079-1082. 